\title{
Teaching Educational Psychology in an International Setting: Exploring the Finnish Education System
}

\author{
Tim Pressley $^{1}$ \\ ${ }^{1}$ Department of Psychology, Christopher Newport University, Newport News, VA, USA \\ Correspondence: Tim Pressley, Department of Psychology, Christopher Newport University 1 Avenue of the \\ Arts, Newport News, VA 23606, USA. 1-757-594-8090. E-mail: timothy.pressley@cnu.edu
}

Received: January 24, 2020

Accepted: March 9, $2020 \quad$ Online Published: June 5, 2020

doi: $10.5539 /$ ies.v13n $7 \mathrm{p} 20$

URL: https://doi.org/10.5539/ies.v13n7p20

\begin{abstract}
The emphasis of this paper is on the importance of teaching teacher preparation courses, specifically educational psychology, through a study abroad trip to Finland. This experience allowed American preservice teachers to see theories applied in an international setting while also allowing preservice teachers to compare the United States education system to the Finnish educational system. The current study includes sixteen female, preservice teachers' perceptions of the trip. Development of the activities abroad occurred with a Finnish university and included multiple school visits, panel discussions, and guest lectures. These experiences allowed for full immersion in the Finnish education system. The data include observations, student papers, and student survey responses, which present changes in students' views of education, views of the Finnish education system, and the application of theories in a real-world setting. This experience not only provided preservice teachers with an opportunity to see one of the best educational systems in the world but also pushed the preservice teachers to rethink how teaching and learning can look in a classroom.
\end{abstract}

Keywords: study abroad, Finland, preservice teachers, educational psychology

\section{Introduction}

Over the last several decades, the United States has worked to catch up to the rest of the world in terms of educational product. The United States implemented countless regulations and policies in order to develop a high-quality educational product for all students. These policies included mandated standardized tests and highly qualified teachers (U.S. Department of Education, 2001; NCLB), implementation of universal curriculum (U.S. Department of Education, 2011; RTTT), and the most recent policy, which gives states more autonomy with public education (U.S. Department of Education, 2015; ESSA). The United States implemented these policies with the goal of supporting low-performing schools and student learning for all students. However, these reforms have created little to no change and the United States has consistently struggled to move up the international rankings compared to other countries (PISA, 2016). When preparing preservice teachers for the classroom, it is important to expose teacher candidates to a wide range of educational approaches to prepare them to teach all students as well as provide examples of how other countries implement a highly effective education system for all students. This study looked at the influence of an international study abroad trip on American preservice teachers' views of education and the advantages of including an international field experience in an educational psychology course.

\subsection{The Finland Education System}

One country, which has seen a great deal of success in education over the past several decades due to educational changes, is Finland (Darling-Hammond, 2010). The Finnish have seen a rise in student performance on international exams such as the Programme for International Student Assessment due to changes in the education system (PISA, 2016; Sahlberg, 2015; Tryggvason, 2009; Välijärvi \& Sulkunen, 2016). Some of these changes included strict requirements for teacher preparation programs, increased focus on student play and creativity in schools, and less focus on standardized assessments (Sahlberg, 2015). One of the major influences behind the educational success is Finland's approach to preservice teachers (Darling-Hammond, 2010; Malinen, Väisänen, \& Savolainen, 2012). To become a teacher in Finland, one must obtain a Master's degree from one of the eight highly competitive teacher preparation programs. Unlike other developed countries, admission to a teacher preparation program is highly competitive, with an acceptance rate of 5-15\% (Malinen et al., 2012; Sahlberg, 
2015). Once in a program, preservice teachers complete extensive teacher preparation, which includes rigorous course work in the pedagogies of teaching, content areas, and research (Malinen et al., 2012; Tryggvason, 2009). Preservice teachers also gain experiences in the classroom via teacher training schools associated with each teacher preparation program (Malinen et al., 2012; Sahlberg, 2015).

Beyond the classroom, Finland has made great strides to support all students in and outside of the classroom. Finnish students find support at schools through free lunch, education, and counseling services offered to all students through the university level (Sahlberg, 2015). Finland has also implemented more time for students to engage in play behavior and required less time in the classroom for instruction (Partanen, 2011). Thus, Finland's educational system differs from the United States on multiple dimensions. Hence, visiting Finland's schools and teacher preparation programs provided an opportunity for United States preservice teachers to examine how Finland approaches education and push American preservice teachers to reevaluate the best approaches for teaching and learning. Though the Finnish culture and society are different from the United States, American preservice teachers need to see other approaches to teaching and learning beyond American classrooms.

The purpose of this study was to explore the impact of an international field experience on preservice teachers. This study looked to add to the field experience literature and the study abroad literature as it focused on a unique study abroad trip to Finland. The current study looked to answer the following research question: 1) How did a study abroad experience in Finland influence preservice teachers learning of educational psychology content? And 2) How did a study abroad experience in Finland influence preservice teachers' views of the United States educational system?

\subsection{Importance of Field Experiences}

One of the challenges when teaching educational psychology, or any education course, is helping students understand the application of the concepts and theories discussed in class. One common approach is using case studies, in-class activities, and videos (Butler \&Weber, 2016; Flowerday, 2016; Shambaugh, 2016). However, in-class activities can only provide a student with limited comprehension of the implementation of theories and practices in a real-world setting.

One way some education courses engage students in the content of a course is through field experiences. These field experiences allow students to observe K-12 classrooms to see the content and theories discussed in class brought to life. Specifically, Shambaugh (2016) states a practicum or field experience is "invaluable to giving students opportunities to implement learning principles and sharing results with one another" (p. 81). Though each field experience is different, a well thought out field experiences for preservice teachers may lead to positive effects learning the content (Darling-Hammond, 2006; 2012; Shambaugh, 2016; Wilson, Floden, \& Ferrini-Mundy, 2001).

Including successful field placements within teacher preparation programs and courses may have a positive impact on the teacher candidates the program produces. Successful field experiences may provide a clear connection to the course and the application to a K-12 classroom. Along with providing real-life examples, preservice teachers often begin to feel more comfortable and develop a higher teaching efficacy from successful field experiences (Flores, 2015; Singh, 2017). Field placements, which include schools with high rates of school success based on achievement gains, have a positive effect on preservice teachers later performance in the classroom (Ronfeldt, 2015). Along with promoting necessary skills for the classroom, these field experiences may also help preservice teachers open their minds to new beliefs regarding teaching and learning (Darling-Hammond, 2006; Feiman-Nemser, \& Buchman, 1987; Shambaugh, 2016). However, one issue with field experiences within the United States is preservice teachers may enter education programs with specific views of education based on growing up within a similar system of the field experience. Though these experiences may be different settings (i.e., more urban or rural), preservice teachers may see the teachers or education systems as similar to past school experiences. Thus, preservice teachers may struggle to adapt their views of a highly effective education (Marx \& Moss, 2011; Pajares, 1992).

\subsection{Theoretical Framework}

In order for teacher preparation programs to prepare future teachers for current classroom settings, Zhao (2010) suggests focusing on global competence. Key aspects of global competence include "foreign language proficiency and a deep understanding of other culture" (p. 425). Zhao (2010) goes on to state that the education system and teacher preparation programs in the United States are not preparing students in the aspect of global competence. One-way, however, teacher preparation programs can expose preservice teachers to diverse classrooms is through study abroad experiences (Cushner, 2009; Cushner \& Mahon, 2009; Marx \& Moss, 2011; Walters, Garii, \& Walters, 2009). Study abroad experiences may expose preservice teachers to other educational 
systems, cultures, and languages.

Along with a lack of global competence, Zhao (2010) shares that education must promote global citizenship, focusing on knowing and respecting other cultures. The ideas of global competence and citizenship are challenging to bring into a classroom discussion, activity, or domestic field experience. However, an international study abroad field provides such an experience for preservice teachers to develop such global awareness (Palmer \& Menard-Warwick, 2012). Including aspects of both global competence and citizenship may help develop preservice teachers into more culturally competent teachers.

Previous studies have focused on preservice teacher study abroad programs and the advantages of study abroad trips, such as exposing to new cultures or developing a fluency in a foreign language (Marx \& Moss, 2011; Palmer \& Menard-Warwick, 2012; Walters et al., 2009). Though no previous studies of teacher preparation study abroad trips have explored one of the top educational systems in the world. Exposing preservice teachers to an educational system such as Finland provides a different model of education than preservice teachers have experienced in the United States and pushes preservice teachers to gain experience in global competence and citizenship. Exposing preservice teachers to the Finnish educational system also provides a model of an educational system that strives for equality for all students and focuses on student needs rather than test scores. Thus, the goal of this study abroad trip was to expose students to a new and highly effective education system as well as provide experiences of learning and understanding of other cultures.

\section{Method}

This qualitative case study (Creswell, 2013) focused on a three-week study abroad trip with preservice teachers completing an educational psychology course in Finland.

\subsection{The Study Abroad Course}

The preservice teachers received course lectures in the basics of educational psychology the week before leaving for Finland, covering key aspects such as learning and motivational theories, classroom diversity, and classroom management. The preservice teachers also read excerpts from the book Smartest Kids in the World and How They Got That Way (Ripley, 2014) to give trip participants background on the Finnish education system. Lastly, the preservice teachers participated in an activity analyzing PISA data, explicitly comparing the United States and Finland. This exercise provided participants a chance to analyze the difference between the two countries' outcomes on an international assessment and begin the conversation about the Finnish education system. Beyond these activities, the preservice teachers had little knowledge of the Finnish education system.

While abroad, the preservice teachers completed two papers and participated in class discussions to further their experience and knowledge of the Finnish system. The papers focused on connecting the course content to observations done in the Finnish schools and a topic of student choice focusing on the Finnish approach to a particular educational issue. Some of the topics for the second paper included special education, standardized testing, and emotional support in schools. The preservice teachers then presented to their papers to the class while in Finland. These papers pushed participants to think critically about the course content and to engage in research on a topic of interest.

\subsection{Experiences in Finland}

In order to provide participants an in-depth experience while in Finland, the professors in charge of the trip connected with a Finnish university to set up educational experiences for the preservice teachers while abroad. These experiences included two half-day visits to local schools, guest lectures by three Finnish professors at the university, and a panel discussion with current preservice teachers at the university. These experiences allowed the preservice teachers to learn more about the Finnish education system, the history of the Finnish education system, and the process one must go through in order to become a teacher in Finland. The school visits included two separate schools, the university's teacher training school, and a local city school. The group received tours at both schools and had discussions with school administrators, teachers, and students.

\subsection{Participants and Data Sources}

The current study included data from the preservice teachers enrolled in the educational psychology course $(n=16)$ at a United States Mid-Atlantic liberal arts university. All participants were female and the educational psychology course is a required prerequisite for the Masters in teaching program at the university. The participants teaching interests included: elementary school (10), middle school (1), and high school (5). The preservice teachers focused on teaching at the secondary levels specifically had interest in teaching English and Music. 
The data sources used to determine the experiences the preservice teachers gained from the trip included course papers, a post-trip survey, and observations during the trip. This qualitative evidence focused on what the preservice teachers learned on the trip and how the trip enhanced their learning of the educational psychology content. The post-trip survey asked the participants five open-ended questions about the course and the content. These questions included: "How did taking educational psychology influence your learning the course content?" "Focusing on education, what were your biggest takeaways from the trip to Finland?" "How do you now view the education system?" "What was your favorite part of the trip?" "What would you change about the trip?" The post-trip survey was not required and 12 participants completed the post-trip survey for a $75 \%$ response rate. The qualitative analysis also included detailed observation notes, taken by the course instructor, during class experiences and discussions.

\subsection{Data Analysis}

A case study design accepts that researchers come with previous background knowledge and experiences that can influence their views during the data collection and analysis (Strauss \& Corbin, 1998). In order to limit any previous experiences or views, all conclusions had to be supported by multiple pieces of data. Lastly, to mitigate any personal biases the researcher used a reflective journal as a reminder of any personal biases, which included: a) the researcher had previous experience teaching educational psychology, thus had extensive knowledge of the content and b) the researcher had previous knowledge of the Finnish system due to background information gained during the planning of the trip.

The researcher initially hand-coded the data using open coding in order to determine codes within individual participants (Strauss \& Corbin, 1998). After coding the teachers' interviews individually, the researcher used axial coding (Strauss \& Corbin, 1998) to develop common themes across participant submissions. Lastly, the researcher used deductive coding to code observation notes using inductive codes found in the papers and surveys in order to strengthen themes. While developing themes, the researcher ensured multiple data sources supported each theme in order to determine significant findings. In order to help validate the qualitative findings, the researcher sent the results section to a randomly selected 5 participants ( $30 \%$ of the sample) for member checking on the accuracy of the results (Creswell, 2013).

\section{Results}

The results indicate the advantages of teaching educational psychology in an international setting to include the importance of field experience and the change in epistemological beliefs of teaching and learning.

\subsection{Importance of Field Experiences}

Multiple preservice teachers shared that providing a field experience in Finland with the course gave them a stronger grasp of the content of the course. As one preservice teacher shared in the post-trip survey, "It was incredibly immersive, and it was so much more real seeing perspectives from other countries and talking to educational staff from other countries than simply hearing about it." Similarly, another shared in her survey answers,

It gave me something to apply and compare. I could see for myself and not just hear about it or watch videos of it in class. I saw teachers using a constructivist approach and talked to students about their goals and attributions of learning. The real-life experiences and hearing things from students there changed how I saw the schools.

An international setting furthered the application of course content because it allowed the preservice teachers to compare how Finland and the United States applied learning and motivational theories differently. "Being able to see the learning and motivational theories put into practice within the classroom furthered my comprehension but also allowed the opportunity to critically examine how two very different educational systems utilize these theories." Thus, the international field experiences not only aided in the learning of the material but also pushed students to think critically about education.

The instructor also observed students bringing up theories throughout the trip during school tours, discussions, and in course papers. During tours, students would often point out to different theories or aspects discussed during the lecture part of the course. Some of the theories brought up during observations and discussions included, the constructivist and social-cognitive approaches used in Finnish schools (Shunk, 2012). The preservice teachers also mentioned motivational theories such as the three major aspects of Self-Determination Theory (Ryan, \& Deci, 2002) and the use of Goal Theory to help students set goals for learning (Locke \& Latham, 2006).

Specifically, students saw aspects of the constructivism theory (Shunk, 2012), which focuses on student learning through experiences. For example, one preservice teacher shared in her paper, "In the classrooms, there was a 
strong constructivist influence with students creating videos in one room and actively using cooperative learning strategies to solve problems in another classroom." Another preservice teacher shared similar observations, "Constructivism has a major influence on how students learn in Finland. For example, students learn to use textiles in crafts class, metals and wood in tech class, learn to do experiments in science, and even learn how to cook." A third preservice teacher noted learning theories seen in the Finnish classrooms. "While I have participated in many class and group discussions growing up, constructivist practices seem much more prevalent in Finland." She went on to state, "it was apparent the class we observed was using social cognitive theory and the student collaboration was a part of almost every lesson throughout the day with this methodology, promoting a sense of autonomy over each student's own learning experience." Beyond just making connections in the term papers, students made connections to theories during school visits, excitedly pointing out theories in action during tours and diving into more detailed discussions of the application of theories post school visits. In both terms papers and class discussions, students pointed out theories such as constructivism, social cognitive, and Self-Determination Theory as more prevalent in Finland than in United States classrooms. Students often shared that the Finnish approach is how they would like to approach teaching, but it may be a challenge due to testing requirements in the United States.

Participants also noted differences in teachers' and students' motivation between the United States and Finland. One preservice teacher noted Finnish teachers approach teaching differently than most American teachers. "Teachers in Finland do not seem to stress about their teaching like American teachers. They fix problems when needed and make sure all students have success." The preservice teachers also noted differences in classroom set-up and student motivation. When it came to student motivation, the preservice teachers noticed how the lack of standardized testing in Finland influenced student motivation. "The Finnish education system places less emphasis on standardized testing and a greater emphasis on inquiry-based learning with a dearth of extrinsic rewards, students are further motivated to learn for enjoyment." This preservice teacher went onto state, "Finnish classrooms do not implement behavior charts or prize boxes, which are often staples in American classrooms. Rather the teachers help students set goals and students work to accomplish a goal successfully."

Another student noted the freedom students have in school. "Students in Finland have an abundance of freedom in their education system. Students are allowed to work on assignments throughout school and play outside with little supervision. This system of trust and freedom builds relationships and competence level of students." Preservice teachers connected observations like this to Self-Determination Theory (Ryan \& Deci, 2002) when discussing student motivation in discussions and papers. Similarly, through a Finnish student panel, the preservice teachers heard and saw positive student relatedness within the school through the positive interactions with teachers, and observed competence within the school environments with student work lining the hallways. As a preservice teacher noted, "the schools and classrooms in Finland were very welcoming and covered in student work, which students took pride in as they gave us tours."

Along with helping the preservice teachers connect the course content to classroom application, the field experiences got the participants more engaged with the course as a whole. Observation of participants during class discussions saw high levels of engagement, with all preservice teachers sharing insights and questions multiple times. As one preservice teacher shared, the preservice teachers looked forward to course discussions to make connections with the course content, their experiences in Finland, and their education.

Being able to see the applications of the content in schools was an amazing experience. I engaged in the class the entire trip and looked forward to our discussions to share my thoughts on Finland's system of education and compare it to my own experiences.

The advantages of including field experience in an educational psychology course increased participant engagement and learning. Including field experience in an international setting seemed to take the engagement and learning even further, the experiences also created life long memories for the preservice teachers. As a preservice teacher shared, "The course content is definitely not something I will forget anytime soon due to the repeated exposure and field experience."

Another important aspect the preservice teachers gained from an international field experience was learning about the Finnish educational system beyond a normal classroom setting. The field experiences on the trip pushed the preservice teachers to engage with the culture and different school settings than they previously experienced. Aspects, which propelled learning, were the experiences at the Finnish university and the local schools. These experiences included discussing the educational system with current Finnish students and faculty members of the local Finnish university. These encounters were key aspects to the trip as it provided students insight into the Finnish education system beyond what a book or a video could share. As one preservice teacher 
shared, "Being able to talk to the students and teachers made the whole experience worthwhile. Walking through the hallways, being in the classrooms and soaking up the atmosphere made me more excited to learn compared to just sitting in a classroom." Another preservice teacher shared the importance of the school visits and how discussions with students provided her a more accurate view of the Finnish education system.

Reviewing literature can give a great impression of how Finland's education system operates, but I would not have gained the (Finnish) student perspectives had we not visited the two schools. I feel as though I have a better-rounded view of how their educational system works.

The field-experiences the preservice teachers participated in during the trip to Finland enhanced the learning experience, but also helped the preservice teachers gain a better understanding of the Finnish approach, which would be hard to replicate in a normal educational psychology lecture. Specifically, the Finnish field experiences provided the preservice teachers a model of a highly effective educational system for all students. As one preservice teacher shared, "Learning and seeing how much support all students receive in school was very eye-opening. I wish the United States provided students with similar aspects, especially free counseling services." Another preservice teacher shared similar feelings, "Seeing all students receive free lunch and have equal resources no matter what school was uplifting. Students were not defined by how much money their parents made or where they lived."

One of the big takeaways was the comparison of education between students in America compared to students in Finland. This comparison was apparent when the preservice teachers interacted with the Finnish students during the school visits. As one student shared, "Seeing all the children who enjoyed going to school compared to the children here (in the United States) was very interesting." Having the preservice teachers interacting with Finnish students allowed the preservice teachers to get first-hand accounts of the impact of the Finnish approach. As a preservice teacher shared in her paper, "Talking with students in Finland, they did not stress about aspects you often hear American students stressed about in school. There was no discussion of standardized testing or grades; students enjoyed school." Students also learned of Finnish concerns regarding testing, as the country has begun to discuss ways to limit student stress over the one matriculation exam at the end of high school. A preservice teacher noted in her paper, "The Finnish are taking a proactive approach to testing rather than ignoring the issue. Providing resources for all students and having an open discussion between educators and policymakers is refreshing to hear."

The school visits and interactions then propelled discussions to think critically about education on a global stage. During discussions, students debated the pros and cons of each education system, the likelihood of implementing a similar system in the United States, and the impact the Finnish system has on students and teachers. The preservice teachers also brought up ways they might apply the learning and motivational theories to future classrooms based on observations at the Finnish schools. These discussions averaged over an hour in time with all students contributed at least two to three times each discussion. As one preservice teacher shared in the post-trip survey, "I loved the discussions we had abroad. It was so fascinating to hear everyone's perspective and to have in-depth conversations about education and what we saw. It made me think about things." The in-class discussions and field experiences were crucial for students to develop their ideas of effective approaches to teaching and learning.

\subsection{Changes in Epistemology}

As the preservice teachers went through the experiences in Finland, they engaged in critical reflection, which pushed them to define highly effective teaching and learning. All of the preservice teachers had experienced the United States educational system from kindergarten to present. These experiences laid the foundation for how they viewed education, their beliefs of effective teaching practices, and the best approaches to learning. As the preservice teachers went through different trip experiences, students' views of education began to shift. This shift in perceptions included students' views of the United States educational system, effective teaching, and their personal goals as future teachers. The changes seen occurred as the preservice teachers discussed the school experiences in Finland, posed questions to each other, and framed the Finnish education system in comparison to the United States. Students also brought in theories of learning and motivation as their definition of a highly effective education system changed.

One of the changes seen in the preservice teachers' views focused on the American educational system. Through the trip, the exposure to the Finnish education system pushed participants to reexamine the education system all of them grew up attending. For example, one preservice teacher shared in her paper, "I realized there were a lot more flaws in the American education system than I had previously known. Having another culture to compare and contrast my experiences helped me realize things we excelled at and things we could improve." A second preservice teacher shared in her post-trip survey, "So many aspects of the American educational system seem 
wrong and outdated after seeing how efficient and practical the Finnish educational system is. It works; America could take some notes." Similarly, a third preservice teacher felt the United States would benefit in using parts of the Finnish approach to education now that they have experienced both approaches.

I have always known there were flaws in the American Education System but did not have a solution in mind until after attending the study abroad experience. Although not everything can transfer to the US, I think we could learn a lot from their system and make large improvements.

Specifically, the preservice noted how many resources are available for all students in Finland. As one preservice teacher noted in her paper, "Students in Finland have access to many free resources including meals in the cafeteria and counseling services. The United States would benefit greatly from providing similar services to all students." Another preservice teacher discussed the number of resources provided to all students. "Students in Finland have many more available resources for all students compared to the United States. It felt like schools put students as the number one priority rather than cutting programs in order to save money."

The experiences abroad also pushed several preservice teachers to share how the experiences in Finland made them reconsider how they would approach teaching in their future classrooms.

I knew I was very educated on the American School System, so learning about Finland's system engaged me immediately. I was then able to think critically about my prior knowledge of schooling and how I could apply strategies to make improvements in my future classroom to improve education.

Similarly, another preservice teacher shared her goals of implementing some Finnish approaches into a future classroom as she saw the positive outcomes with students. "I hope I can find ways to give my future students as much autonomy as we saw in Finland. Students were engaged and enjoying learning rather than completing a worksheet or preparing for a test." This was a common attitude for the whole group, who often discussed ways to implement a Finnish approach in their future classrooms. Examples of discussed during classes included, allowing students more time for play and creativity, working within students zone of proximal development, promoting problem solving with students, and providing more student autonomy within the classroom.

Other aspects the preservice teachers felt the Finnish system did well were incorporating new ideas, real-world experiences, and technology into the classroom. Examples of real-world skills incorporated in the classroom included seeing Finnish students learning life skills such as sewing, welding, and operating a 3-D printer in the general curriculum. The preservice teachers felt including real-world skills was important for developing well-rounded students, something the preservice teachers did not feel was happening in the United States. Though the preservice teachers knew they could not change the curriculum, they often brought up in discussion how they might incorporate technology and real-world experiences in their future classrooms. Examples of potential activities for future classrooms shared during discussions included implementing student-made videos on tablets, teaching across subjects such as developing a cooking lesson with math terms, and implementing more student autonomy in projects. All preservice teachers shared they became more aware of the advantages and disadvantages of different educational systems from the trip, and they hoped to incorporate approaches to teaching and learning observed in Finland in their classrooms.

\section{Discussion}

The current study found teaching an education course, such as educational psychology, as a study abroad course in Finland afforded some significant advantages in instruction and learning for preservice teachers. These advantages included preservice teachers applying course content to field experiences, learning about one of the top educational systems in the world through direct experiences, and changes in preservice teachers' epistemology of education. The experiences the preservice teachers engaged in while abroad, specifically the field experiences, influenced changes in educational views, strengthened the learned course content, and promoted global competence and citizenship (Zhao, 2010). These findings support previous studies, which found field experiences enhance learning for preservice teachers (Darling-Hammond, 2006; Feiman-Nemser \& Buchman, 1987; Shambaugh, 2016). This is especially true for study abroad experiences, which show support for pushing students to develop new perspectives and attitudes based on international experiences (Marx \& Moss, 2011; Palmer \& Menard-Warwick, 2012; Sharma, Phillion, \& Malewski, 2011). Study abroad trips, especially ones focused on international education, may help preservice teachers understand global competence and citizenship as well as helping them develop into culturally competent teachers (Taylor, Yeboah, \& Ringlaben, 2015; Zhao, 2010). International study abroad courses for preservice teachers may also help future teachers grasp how other countries approach teaching and supporting all students.

The current educational psychology course, when taught in the United States, typically does not have a field 
experience; however, the advantages seen in this study support the importance of including one in future semesters. The findings from this study and previous studies on field experiences suggest other preservice programs should consider implementing more field experiences for students in order to promote the application of topics discussed in lectures. Field placements, especially the ones on this trip, allowed the preservice teachers on the trip to Finland to see current classroom practices of a top educational system. The current trip allowed the preservice teachers themselves, through directly experiencing a different educational system, to construct new knowledge about educational systems and exposed them to cultures that could not have happened had they remained within the US educational system for the course (Marx \& Moss; Pajares, 1992; Zhao, 2010).

United States preservice teachers typically are educated within the US educational system. Thus, their views of education are limited by their own experiences. Often, this limited view is seen in the typical United States delivered educational psychology courses, where students often have difficult time thinking beyond and breaking free of their own experiences and understandings of the US education system as "the way education is." A trip, such as this one to Finland, allowed preservice teachers to construct a new vision and understanding of teaching and learning as well as promote global competence and citizenship. This included gaining new perspectives on education, different ways of supporting students within a school environment, and an alternate approach to education. The preservice teachers worked through their new understandings of education by hearing from students, teachers, administrators, and professors. Receiving information from a variety of stakeholders provided different perspectives on education in Finland. The results suggest teacher preparation programs should consider including different interactions for preservice teachers in courses and field placements. The current study found initiating interactions with all levels of educational stakeholders, allowed the preservice teachers to hear multiple viewpoints. For example, meeting with building administrators along with field experiences allowed the preservice teachers to learn about education from a building administrator rather than just a classroom teacher perspective. Including similar interactions in the United States may lead to preservice teachers having a different perspective on educational initiatives used in the United States. These new perspectives may be valuable once working as a classroom teacher.

When it came to developing the preservice teachers beyond the classroom, the trip also helped develop global competence and citizenship (Zhao, 2010) in the preservice teachers. This development may push students to be more open-minded to diversity and acceptance of all within their future classrooms (Cushner, 2009; Cushner \& Mahon, 2009; Walters et al., 2009). As classrooms in the United States become more diverse, it is essential to prepare preservice teachers to be accepting and welcoming to differences within the classroom (Palmer \& Menard-Warwick, 2012). Though Finland has much less diversity than seen in the United States, students experienced culture shock and interacted with people who were different from them by background, language, and culture. These experiences allowed the preservice teachers the opportunity to work through challenges such as communicating with individuals. These challenges faced abroad may support preservice teachers' future approaches with English Language Learners (ELL) and English as a Second Language (ESL) students in future classrooms (Medina, Hathaway, \& Pionieta, 2015; Williams \& Abramenka, 2018). Lastly, the preservice teachers learned how another country approached changes in educational policy. Finland's approach to supporting students in and outside of the classroom is different from most United States schools. These differences include focusing on student mental health and promoting learning with all SES groups. Seeing the support students receive in Finland may push the preservice teachers to advocate for more student support in their future schools.

\subsection{Limitations}

The current qualitative case study focused on one field experience in Finland, and due to the qualitative nature of this study, the findings may not generalize to all field experiences or international experiences. Another limitation of this study is the number of preservice teachers who participated in the trip and the data collection. However, the research on experiences such as the one in this current study is limited. Readers should note that other field experiences or international experiences may not provide the same opportunities for students and thus may not have similar success. The success of a study abroad experience will be dependent on several different variables, some of which will be in or out of instructor control. More research needs to explore other countries and international field experiences to help expand the current literature on teaching courses in an international setting.

\subsection{Implications and Conclusion}

Implementing a study abroad trip, especially a short-term study abroad, takes a great deal of preparation and planning. Faculty members planning a short-term abroad should be cognizant of the overall goals of the trip as they go through the planning process. For this particular trip, connecting with a local university was extremely 
useful as it provided contacts in Finland and support to set up the necessary educational experiences. This connection also allowed the faculty member to inquire about lodging, transportation, and other activities from locals.

With all field experiences, it is vital to prepare students for what to expect; however, in an international setting, it is also essential to prepare students for the cultural differences. As noted by Richardson, Imig, and Flora (2014), the pre-departure meetings may impact the overall experience students have abroad. Thus, in order to help students prepare for the trip, the instructor of the trip used several approaches. Having completed a pre-trip visit to Finland the summer before, the instructor was able to guide students on cultural norms, insight on local activities, and places to eat. The professor also used videos found online to provide insight into the cultures students would experience on the trip. Lastly, the professor recruited several Finnish students currently enrolled at the university to speak to the group before the trip. The native Finnish students provided a first-hand experience of the culture with a direct comparison to the United States culture and allowed students to ask questions to a native before departing for the trip.

Along with the educational experiences, a study abroad trip is an effective way for students to experience the local culture as well as other cultures in the area. During the two-weeks abroad, the group spent time in Helsinki and Turku, Finland, as well as Stockholm, Sweden, and Tallinn, Estonia. These experiences not only allowed the preservice teachers to learn about the Finnish culture but also explore other cultures one does not get in a university lecture hall (Palmer \& Menard-Warwick, 2012). However, not all visits focused on the education systems of each country, the exposure to the other cultures provided a more global view for the preservice teachers. The preservice teachers shared the experiences in multiple countries enjoyed provided more cultural experiences beyond the educational experiences of a teacher preparation course.

Overall, this trip provided preservice teachers an opportunity to see one of the top education systems in the world and to expand participants' global competence. These opportunities may help future teachers approach education and teaching differently due to their experiences in Finland. This trip to Finland pushed the preservice teachers to think critically about the current state of the United States education system and how future educators like themselves can make changes. From a professor's standpoint, the growth and changes in beliefs are valuable experiences for the preservice teachers to have before entering the classroom. These changes will hopefully lead to the preservice teachers approaching education differently as they enter future classrooms with a more global view of teaching and learning.

\section{References}

Butler, A. G. \& Weber, L. N. (2016). Lessons from The Karate Kid: Using popular movies in educational psychology. In M. C. Smith, \& N. Defrates-Densch (Eds.), Challenges and innovations in educational psychology teaching and learning (pp. 83-96). Charlotte: Information Age Publishing.

Creswell, J. W. (2013). Qualitative inquiry \& research design: Choosing among five approaches (3rd ed.). Los Angeles, CA: Sage Publications.

Cushner, K. (2009). The role of study abroad in the preparation of globally responsible teachers. In L. Ross (Ed.), Study abroad and the making of global citizens: Higher education and the quest for global citizenship (pp. 151-169). New York: Routledge.

Cushner, K., \& Mahon, J. (2009). Developing the intercultural competence of educators and their students: Creating the blueprints. In D. Deardorff (Ed.), Handbook of intercultural development (pp. 34-320). Thousand Oaks, CA: Sage.

Darling-Hammond, L. (2006). Constructing 21st-century teacher education. Journal of teacher education, 57(3), 300-314. https://doi.org/10.1177/0022487105285962

Darling-Hammond, L. (2010). What we can learn from Finland's successful school reform. NEA Today Magazine, 29(2), 1-9.

Feiman-Nemser, S., \& Buchmann, M. (1987). When is student teaching teacher education?. Teaching and teacher education, 3(4), 255-273. https://doi.org/10.1016/0742-051X(87)90019-9

Flores, I. M. (2015). Developing Preservice Teachers' Self-Efficacy through Field-Based Science Teaching Practice with Elementary Students. Research in Higher Education Journal, 27.

Flowerday, T. (2016). Using motivation to teach motivation. In M. C. Smith, \& N. Defrates-Densch (Eds.), Challenges and innovations in educational psychology teaching and learning (pp. 109-122). Charlotte: Information Age Publishing. 
Locke, E. A., \& Latham, G. P. (2006). New directions in goal-setting theory. Current directions in psychological science, 15(5), 265-268. https://doi.org/10.1111/j.1467-8721.2006.00449.x

Malinen, O. P., Väisänen, P., \& Savolainen, H. (2012). Teacher education in Finland: a review of a national effort for preparing teachers for the future. Curriculum Journal, 23(4), 567-584. https://doi.org/10.1080/09585176.2012.731011

Marx, H., \& Moss, D. M. (2011). Please mind the culture gap: Intercultural development during a teacher education study abroad program. Journal of teacher education, 62(1), 35-47. https://doi.org/10.1177/0022487110381998

Medina, A., Hathaway, J., \& Pionieta, P. (2015). How preservice teachers' study abroad experiences lead to changes in their perceptions of English Language Learners. Frontiers: The Interdisciplinary Journal of Study Abroad, 25, 73-90.

Pajares, M. F. (1992). Teachers' beliefs and educational research: Cleaning up a messy construct. Review of Educational Research, 62(3), 307-332. https://doi.org/10.3102/00346543062003307

Palmer, D. K., \& Menard-Warwick, J. (2012). Short-term study abroad for Texas preservice teachers: On the road from empathy to critical awareness. Multicultural Education, 19(3), 17-26.

Partanen, A. (2011). What Americans keep ignoring about Finland's school success. The Atlantic.

Programme for International Student Assessment (PISA). (2016). PISA Test. Retrieved from http://www.oecd.org/pisa/

Richardson, J. W., Imig, S., \& Flora, K. (2014). Evaluating school leadership development through an international experience. International Journal of Leadership in Education, 17(3), 353-369. https://doi.org/10.1080/13603124.2013.817611

Ripley, A. (2014). The smartest kids in the world and how they got that way. New York: Simon \& Schuster Paperbacks.

Ronfeldt, M. (2015). Field placement schools and instructional effectiveness. Journal of Teacher Education, 66(4), 304-320. https://doi.org/10.1177/0022487115592463

Ryan, R. M., \& Deci, E. L. (2002). Self-determination theory and the facilitation of intrinsic motivation, social $\begin{array}{llll}\text { development, and } & \text { american }\end{array}$ https://doi.org/10.1037/0003-066X.55.1.68

Sahlberg, P. (2015). Finnish lessons 2.0: What can the world learn from educational change in Finland? New York, NY: Teachers College Press.

Shambaugh, N. (2016). Understanding motivation theories using project-based learning. In M. C. Smith, \& N. Defrates-Densch (Eds.), Challenges and innovations in educational psychology teaching and learning (pp. 205-218). Charlotte: Information Age Publishing.

Sharma, S., Phillion, J., \& Malewski, E. (2011). Examining the practice of critical reflection for developing pre-service teachers' multicultural competencies: Findings from a study abroad program in Honduras. Issues in Teacher Education, 20(2), 9-22.

Shunk, D. H. (2012). Learning theories: An educational perspective. Boston, MA: Pearson.

Singh, D. K. (2017). Role of clinical practice in teacher preparation: Perceptions of elementary teacher candidates. Education, 138(2), 179-189.

Strauss, A., \& Corbin, J. (1998). Basics of qualitative research (2nd ed.). Thousand Oaks: Sage.

Taylor, R., Yeboah, A. K., \& Ringlaben, R. P. (2015). Pre-service teachers' perceptions towards multicultural education and teaching of culturally and linguistically diverse learners. International Journal of Innovation Education and Research, 3(9), 42-48.

Tryggvason, M. T. (2009). Why is Finnish teacher education successful? Some goals Finnish teacher educators have for their teaching. European Journal of Teacher Education, 32(4), 369-382. https://doi.org/10.1080/02619760903242491

U.S. Department of Education. (2001). No Child Left Behind (NCLB). Retrieved from http://www2.ed.gov/nclb/landing.jhtml

U.S. Department of Education. (2011). Race to the Top Fund (RTTT). Retrieved from 
http://www2.ed.gov/programs/racetothetop/index.html

U.S. Department of Education. (2015). Every Student Succeeds Act (ESSA). Retrieved from https://www.ed.gov/essa?src=rn

Välijärvi, J. \& Sulkunen, S. (2016). Finnish schools in international comparison. In H. Niemi, A. Toom, \& A. Kallioniemi (Eds.), Miracle of education: The principles and practices of teaching and learning in Finnish schools (pp. 3-22). Rotterdam: Sense. https://doi.org/10.1007/978-94-6300-776-4_1

Walters, L. M., Garii, B., \& Walters, T. (2009). Learning globally, teaching locally: Incorporating international exchange and intercultural learning into preservice teachers-service teacher training. Intercultural Education. 20(1-2), 151-158. https://doi.org/10.1080/14675980903371050

Williams, S., \& Abramenka, A. (2018). The motivations of U.S. preservice teaching graduates returning to teach. Journal of Teacher Education and Educators, 7(3), 243-262.

Wilson, S. M., Floden, R. E., \& Ferrini-Mundy, J. (2001). Teacher Preparation Research. Current Knowledge, Gaps, and Recommendations. Washington: Center for the Study of Teaching and Policy.

Zhao, Y. (2010). Preparing globally competent teachers: A new imperative for teacher education. Journal of Teacher Education, 61(5), 422-431. https://doi.org/10.1177/0022487110375802

\section{Copyrights}

Copyright for this article is retained by the author(s), with first publication rights granted to the journal.

This is an open-access article distributed under the terms and conditions of the Creative Commons Attribution license (http://creativecommons.org/licenses/by/4.0/). 